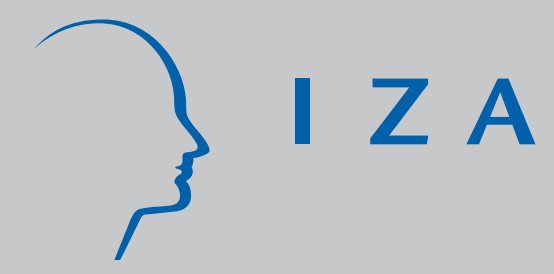

IZA DP No. 3006

Are Muslim Immigrants Different in Terms of Cultural Integration?

Alberto Bisin

Eleonora Patacchini

Thierry Verdier

Yves Zenou

August 2007 


\title{
Are Muslim Immigrants Different in Terms of Cultural Integration?
}

\author{
Alberto Bisin \\ New York University
}

Eleonora Patacchini

University of Rome "La Sapienza"

Thierry Verdier

PSE and CEPR

Yves Zenou

Stockholm University, GAINS, CEPR, Research Institute of Industrial Economics and IZA

Discussion Paper No. 3006

August 2007

\author{
IZA \\ P.O. Box 7240 \\ 53072 Bonn \\ Germany \\ Phone: +49-228-3894-0 \\ Fax: +49-228-3894-180 \\ E-mail: iza@iza.org
}

\begin{abstract}
Any opinions expressed here are those of the author(s) and not those of the institute. Research disseminated by IZA may include views on policy, but the institute itself takes no institutional policy positions.

The Institute for the Study of Labor (IZA) in Bonn is a local and virtual international research center and a place of communication between science, politics and business. IZA is an independent nonprofit company supported by Deutsche Post World Net. The center is associated with the University of Bonn and offers a stimulating research environment through its research networks, research support, and visitors and doctoral programs. IZA engages in (i) original and internationally competitive research in all fields of labor economics, (ii) development of policy concepts, and (iii) dissemination of research results and concepts to the interested public.
\end{abstract}

IZA Discussion Papers often represent preliminary work and are circulated to encourage discussion. Citation of such a paper should account for its provisional character. A revised version may be available directly from the author. 
IZA Discussion Paper No. 3006

August 2007

\section{ABSTRACT}

\section{Are Muslim Immigrants Different in Terms of Cultural Integration?*}

Using the UK Fourth National Survey of Ethnic Minorities, we explore the determinants of religious identity for Muslims and non-Muslims. We find that Muslims integrate less and more slowly than non-Muslims. A Muslim born in the UK and having spent there more than 50 years shows a comparable level of probability of having a strong religious identity than a nonMuslim just arrived in the country. Furthermore, Muslims seem to follow a different integration pattern than other ethnic and religious minorities. Specifically, high levels of income as well as high on-the-job qualifications increase the Muslims' sense of identity. We also find no evidence that segregated neighborhoods breed intense religious and cultural identities for ethnic minorities, especially for Muslims. This result casts doubts on the foundations of the integration policies in Europe.

JEL Classification: A14, J15

Keywords: religious identity, assimilation, Muslims

Corresponding author:

Yves Zenou

Department of Economics

Stockholm University

10691 Stockholm

Sweden

E-mail: yves.zenou@ne.su.se

* This paper is part of the Polarization and Conflict Project CIT-2-CT-2004-506084 funded by the European Commission-DG Research Sixth Framework Programme. 


\section{Introduction}

An intense political and intellectual debate is taking place in Europe around migration issues. Rather than being centered on the economic costs and benefits of such inflows, the debate has instead focused on the perceived costs and benefits of cultural diversity. ${ }^{1}$

This debate has been particularly intense with respect to Muslim immigrants. The recent (November 2005) riots in Paris' suburbs (most of the rioters were the French-born children of immigrants from Arab and African countries, a large percentage being Muslim), the terrorist attacks in Madrid (March 2004) and London (July 2005), the killing of the author of a documentary about Muslim immigrants by a young Dutch-Moroccan in Amsterdam (November 2004), the riots in many Muslim communities after the publications of vignettes representing the prophet Mohammed in a Danish newspaper (February 2006), all are sparking doubts and worries about the ability and the willingness of Muslim immigrants to assimilate into Western society.

The request of the Catholic church that the constitution of the European Community referred to Christianity as a foundational character of Europe, as well as the widespread opposition to the admission of Turkey to the Community itself, are all political and ideological reactions to multiculturalism and, in particular, to the recent Muslim immigration in Europe.

In this paper, we attempt a first empirical analysis of religious identity with the particular objective of understanding if identity acquisition and integration patterns are significantly different between Muslims and other immigrants.

Religious traits tend to be very resilient. Historical examples of religious groups mistakenly singled out for their "inability to assimilate" abound. Between 1815 and 1860, for instance, the large inflow of Catholic immigrants in the U.S., and their "clannishness and separatism" aroused antiCatholic and anti-foreign resentment among large fractions of the Protestant majority (see, in particular, the essay on "American Identity and Assimilation", in Thernstrom et al., 1980).

Is the resentment against Muslims immigrants in Europe nowadays also a transient reaction to the generally resilient character of culture and religion? Or are the Muslim different from other immigrants in terms of cultural integration?

\footnotetext{
${ }^{1}$ Huntington $(1993,1996)$ 's notion of clash of civilization has served as a focal point for those who believe multi-cultural societies are simply not feasible. In his book, Sen (2006) has opposed these views.
} 
In this paper, we aim at shedding some light on this issue using the detailed information provided by a unique UK data set, the Fourth National Survey of Ethnic Minorities (FNSEM). The FNSEM asks a variety of questions on individual's ethnic and religious preferences (such as importance of religion, attitudes towards inter-marriage, and relevance of ethnicity in choosing the children's school). We encode the answers to these questions to produce various measures of intensity of each individual's religious identity, distinguishing Muslims and non-Muslims. We then study the determinants of religious identity. We especially attempt at identifying any significant difference between Muslims and non-Muslims in order to examine whether the assertion that the process of cultural integration is quantitatively and qualitatively different for the Muslims than for the other UK minorities in the sample (e.g., Carribeans, Chinese, non-Muslim Indians) is true.

First of all, we document a stronger intensity of religious identity on the part of the Muslims. Muslims and non-Muslims immigrants however differ in terms of several demographic and socio-economic characteristics, like e.g., age of arrival in the UK, education, income, etc., which could in principle explain their different observed attitudes towards religious identity and integration. We therefore attempt at identifying the relative contribution of the different demographic and socio-economic characteristics in shaping the integration process of Muslims and non-Muslims. Our analysis reveals that the integration pattern adopted by Muslim immigrants in the UK contains in fact several important specific aspects. In particular, Muslims do not seem to assimilate with the time spent in the UK, or at least they seem to do so at a much slower rate than non-Muslims. Also, education does not seem to have any effect on the attenuation of their identity, and job qualification as well as living in neighborhoods with low unemployment rate seem to accentuate rather than moderate the identity formation of Muslims.

Furthermore, for Muslims more than for non-Muslims, there is no evidence that segregated neighborhoods breed intense religious and cultural identities. Finally, discrimination, which turns out to be more frequent in less segregated neighborhoods, does consistently generate intense identity, more so for Muslims. We interpret these last results as casting some doubts on the European integration policies, which favor the formation of geographical integration and mixed neighborhoods. 


\section{Description of the data}

The Fourth National Survey of Ethnic Minorities (FNSEM) was collected in 1993/94 in the UK by the Policy Studies Institute. The FNSEM oversamples ethnic minority groups (see Modood et al., 1997, for details) and provides extensive information about respondents' identification with their own ethnic and religious group (including a question asking the respondent to identify her/his religious faith). The ethnic population is composed of six groups (Caribbean, Indian, Pakistani, African-Asian, Bangladeshi, and Chinese) ${ }^{2}$ several of which having a significant Muslim component; notably Pakistanis and Bangladeshis are predominantly Muslims, while Indians and Africans-Asians have substantial Muslim minorities. The data are merged with the 1991 Census in order to get valuable information of each individual's residential ward. ${ }^{3}$

The FNSEM contains a number of questions providing information on different dimensions of identity, in particular (i) importance of religion, (ii) attitudes towards inter-marriage and (iii) the relevance of ethnicity in influencing the kind of school people want for their children. We use the answers to these questions to measure the intensity of each individual's religious identity. Each of answer is coded as a dichotomous variable. For the first variable ("importance of religion"), it takes value one if the individual considers very important the role of religion in her/his life and zero otherwise. For the second one ("attitude towards inter-marriage"), it takes value one if the individual would mind very much if a close relative were to marry a white person. Finally, for the third variable ("importance of racial composition in schools"), it takes value one if the reported (desired) proportion of one's ethnic group in the children's school is more than a half and zero otherwise. ${ }^{4}$ These alternative indicators of religious identity are used in our analysis in turn. We obtain a final sample of 5,963 individuals, divided between 3,594 non-Muslims and 2,369 Muslims (roughly 40\% of the total).

Table 1 displays the descriptive statistics of our variables, differentiating between Muslims and Non-Muslims. The average Muslim individual clearly appears to be more attached to her/his culture of origin. Indeed, regardless of the dimension of identity considered, the percentage of Mus-

\footnotetext{
${ }^{2}$ For historical reasons Black Africans were not included. Furthermore, the survey only covers England and Wales.

${ }^{3}$ A UK Census ward contains on average 3,000-4,000 residents.

${ }^{4} \mathrm{~A}$ different coding of these variables (i.e., allowing more than two levels) that leads to the estimation of an ordered probit specification does not change qualitatively our results.
} 
lims having an intense religious identity is roughly twice as much as that of non-Muslims. A greater resistance to cultural integration is also signaled by the percentage of Muslims speaking English at home or with friends, always significantly lower than those of non-Muslims. Finally, Muslims have almost twice the probability of having a marriage arranged by their parents than non-Muslims, also a sign of attachment to cultural and religious traditions. ${ }^{5}$

Importantly, the stronger resistance to integration, which our data documents for Muslims immigrants, can hardly be explained by a difference in the time spent in the UK since it is (on average) not statistically different between Muslims and non-Muslims. However, on average, Muslims are less educated than non-Muslims, with a lower household income, and with more than twice as much chance to be unemployed. Muslims also live in more ethnic segregated areas, which have higher unemployment rates. To what extent these and other demographic and socio-economic contextual characteristics of Muslim immigrants in the UK explain their differential attachment to their religion and associated cultural traits?

[Insert Table 1 here]

\section{What determines a strong religious identity?}

We estimate a probit model in which the outcome variable is intensity of religious identity. Our three indicators of identity are used as three alternative dependent variables. The estimation results for these three different specifications are reported in Table 2, for Muslims and non-Muslims separately. In addition to an extensive set of individuals' observable characteristics (i.e., education, sex, fertility choices, employment status, job qualification, macro-region of residence, years since arrival in UK, age at arrival, and whether the individual is born in UK), we gradually introduce variables aiming at capturing the influence of the social environment (family, friends, neighbors) and workplace, using the language typically spoken in the family, with friends and at work. Differences in income and wealth across individuals are accounted for by the inclusion of household income. We also include the ward percentage of own ethnic group residents and the ward unemployment rate. Finally, we include as a regressor a measure of the average discrimination suffered by individuals in the sample by ethnic

\footnotetext{
${ }^{5}$ Muslims have also more children than non-Muslims, they are more likely to have parents living away from them (typically in their country of origin), and, compared to non-Muslims, make larger use of letters as opposed to visits and telephone calls.
} 
group. We report in Table 2 the estimation results for the model specifications that include the more extensive set of explanatory variables (the corresponding summary statistics are in Table 1). Precise definitions of these variables can be found in Appendix 1.

Interestingly, we find that the responsiveness to the different variables varies largely between Muslims and non-Muslims. For non-Muslims, a high level of education (being highly educated in Britain) and a high qualification (being a manager) are among the most important factors that reduce their sense of identity. For Muslims, instead, education does not seem to have any effect on the attenuation of their identity and, on the contrary, being a manager as well as having a high income seem to strengthen their religious faith. On the contrary, Muslims living in areas with a lower unemployment rate seem to display a higher sense of identity. Going back to Table 1, the picture that emerges is that, although Muslims are poorer and less likely to become managers than non-Muslims, those who succeed show a stronger religious faith.

\section{[Insert Table 2 here]}

Most importantly, even after conditioning on the various individual and contextual demographic and socio-economic characteristics discussed above, the speed of cultural integration is lower for Muslims than for nonMuslims. While for non-Muslims, the longer the time since arrival in the UK, the more attenuate is the attachment to their culture of origin, for Muslims, the number of years since arrival does not have any significant effect on their inclination to assimilate (only at the $10 \%$ level for the first specification). Being born in the UK decreases the intensity of religious identity also for Muslims, but this impact is more than two times larger for non-Muslims than for Muslims. Furthermore, the effect of age at arrival, for constant time spent in the UK, although being not statistically significant, is negative for the Muslims and positive for the non-Muslims. This possibly indicates that strong identity is picked up by the Muslims in the UK, rather than being carried over from personal experiences or memories from the country of origin. This also appears as a specificity of the Muslims' integration pattern.

Interesting (and perhaps surprising) results are obtained also with regards to the dependence of identity on the neighborhood composition. We find that living in a more integrated neighborhood (with a lower percentage of own ethnic/religious minority group) and speaking English at work, which signals a mixed working environment, are both associated with a higher sense of identity. This integration pattern is common to both Mus- 
lims and non-Muslims, but it appears to be more marked for Muslims. It suggests that intense forms of identities appear to be formed in social contexts in which the minority ethnic/religious trait is more exposed to the interaction with the majority norm of behavior, perhaps as a reaction to the norms of the majority or its demand for integration of immigrant populations. It should be noted that episodes of harassment and discrimination tend to have relatively higher frequency in less segregated neighborhoods. ${ }^{6}$ Consistently, the average by ethnic group of instances of discrimination suffered by individuals in the sample has a positive effect on identity, and it is stronger for Muslims than for non-Muslims.

\section{Robustness check: Neighborhood choice}

If ethnic minorities congregated in specific neighborhoods because of some unobservable characteristics that affected their religious identity, our analysis of the relationship between neighborhood segregation and identity would be invalid and the estimates biased. More specifically, to invalidate our analysis, it would be required that immigrants with stronger preferences for religious identity endogenously choose to reside in less segregated neighborhoods.

In this section, we address the possible endogeneity of neighborhood choice. To this end we document within the limitations of our data that, in our sample, our results holds true when ethnic-related considerations do not drive in a fundamental manner the individuals' decisions to reside in a specific ward.

Unfortunately our data source does not provide a direct question on the reasons underlying the location of individuals in a given neighborhood. However, the questionnaire asks the individuals their judgment on the quality of the residential area in terms of ethnic composition and whether, given a location choice, they would prefer to move or to stay in the area. We therefore select a sub-sample of respondents composed of individuals (i) who state that the neighborhood in which they reside is "poor" for "being with other people of their own ethnic group" but nonetheless they declare they do not wish to move; and individuals (ii) who state that the neighborhood in which they reside is "good" for "being with other people of their own ethnic group" but nonetheless they declare they do wish to move. These two groups contain the individuals for whom, in our interpretation,

\footnotetext{
${ }^{6}$ In our data, the frequency of serious episodes of racial harassment (like e.g., attacks) is more than double in mixed than in segregated neighborhoods (19\% and $9 \%$ respectively).
} 
the choice of the residential neighborhood is likely to be exogenous with respect to their concerns about the ethnic composition of the neighborhood.

Note that by restricting the sample we are not simply selecting people that do not value highly their own identity. Table 3 shows that people from any of these two restricted samples do not tend to respond to identityrelated questions in a way systematically different than people from the larger sample.

\section{[Insert Table 3 here]}

Thus, in order to check whether our evidence is driven by endogeneity issues stemming from the individuals' residential location choices, we run our analysis on these two sub-samples, within the Muslim and nonMuslim groups. Table 4 reports the results of this robustness check, when "importance of religion" is used as dependent variable. ${ }^{7}$

\section{[Insert Table 4 here]}

It appears that the results are not qualitatively different across subsamples and from the ones referring to the whole samples of Muslims and non-Muslims (Table 2).

\section{Discussion of results and policy implications}

Muslims in our data integrate less and more slowly than non-Muslims, even after conditioning on a rich set of individual and contextual demographic and socio-economic characteristics. As an illustration, we show in Figure 1 the integration patterns over time for first and second generation immigrants, for Muslims and non-Muslims separately. ${ }^{8}$

\section{[Insert Figure 1 here $]$}

\footnotetext{
${ }^{7}$ The results obtained using our alternative dimensions of identity remain qualitatively unchanged.

${ }^{8}$ These results are obtained from the estimation of a specification of our model where interaction terms between the dummy "born in the UK" and "time spent in the UK" (that is equal to "age" if born in the UK and to "years since arrival" otherwise) and its square have been added. Because we find evidence that different explanatory variables have a different impact for Muslims and non-Muslims the model has been estimated separately for each group. We plot the marginal effects (i.e. the changes in the average probability of having a strong religious identity following a one-year increase in time spent in the UK) obtained when using "importance of religion" as dependent variable. The graphs remain qualitatively unchanged when using our alternative measures of religious identity.
} 
Within each group, second generation immigrants have a lower probability of showing a high attachment to their culture of origin over time, but this reduction is more marked for non-Muslims than for Muslims. More interestingly, the years spent in the UK have virtually no effect on the level of religious identity of Muslims, whereas they decrease that of non-Muslims. The marginal effects (i.e. changes in the probability of having a strong religious identity following a one-year increase in the time spent in the UK at different points in time) decline for both Muslims and non-Muslims, but the average effect over time (i.e., the average rate of integration) for nonMuslims is more than three times bigger than for Muslims (more than $-3 \%$ and less than $-1 \%$, respectively). Figure 1 also shows that, when the effects of our large set of individual and contextual characteristics have been accounted for, a Muslim born in the UK and having spent there more than 50 years has on average the same probability of having a strong religious identity as a first generation non-Muslim who has been in the UK for less than 20 years. Second generation Muslims never achieve the (lower) level of probability of having a strong religious identity of second generation non-Muslims at any point in time.

These results are at odds with that of Manning and Roy (2007) who, using the UK Labour Force Survey in 2001, find "no evidence of a culture clash in general, and one connected with Muslims in particular." More specifically, Manning and Roy (2007) adopt a measure of integration constructed from answers to the question: "What do you consider your national identity to be? Please choose as many or as few as apply." Using this measure they document that a large fraction of those individual in the sample who are born in Britain actually report a British national identity and that such a fraction is larger for third than for second generation immigrants. ${ }^{9}$ The measure of integration adopted in our paper is however conceptually distinct, as it is constructed from questions regarding importance of religion, attitude towards inter-marriage, and importance of racial composition in schools. It is very well possible that integration in terms of national identity, as measured by Manning and Roy (2007), follows a very different pattern than the integration in terms of attitudes towards religion, marriage, and schooling, which is what we attempt to measure here. Consistently with this explanation, Constant et al. (2006) adopt a definition of integration that accounts for several cultural and religious factors, including social interactions, and find significantly different integration patterns for Muslims and Christians in the German Socioeconomic Panel 2001. No

\footnotetext{
${ }^{9}$ See also Modood et al. (1997).
} 
doubts, however, that more data and more theoretical work are necessary to better understand such a complex topic as integration.

We also find no evidence that segregated neighborhoods breed intense religious and cultural identities. While this result might appear surprising, it is consistent with other documented evidence of identity formation. Notably, Fryer and Torelli (2005) find that "acting white" behavioral norms among blacks (i.e., associating academic success to lack of identity) are more developed in racially mixed schools. More generally, Putnam (2007) cites consistent evidence in sociology on the dependence of several socioeconomic dimensions of identity (e.g., cohesion across work-groups, social trust across neighborhoods, cooperative behavior in the field and in the lab) on ethnic diversity. More directly, Putnam (2007), using data from the Social Capital Community Benchmark Survey in the U.S. in 2000, also documents a negative effect of ethnic heterogeneity at the neighborhood level on social capital (measured from answers to a survey question regarding trust in neighborhoods). Finally, Bisin, Topa, and Verdier (2004) document that religious socialization across U.S. states is more intense when a religious faith is in minority. ${ }^{10}$

Having documented no positive relationship between geographic segregation and identity is important because it stands in contrast with the intellectual foundation of most immigration policies in Europe. ${ }^{11}$ The Commission on Racial Equality, instituted by the UK government in 1996 and one of the most active institutions in proposing and evaluating immigration policies in Europe, for instance, puts integration at the center of its objectives. Trevor Phillips, the head of this Commission, concerned about geographic segregation ("when we leave work, most of us leave multi-ethnic Britain behind"), famously called for action to prevent Britain "sleepwalking to segregation." The recent ethnic and racial riots mentioned in the introduction are certainly an indication that the different European integration policies have not been very successful. Our empirical results suggest that the intense and oppositional identities that give rise to such social conflicts are not directly favored by the segregation of the neighborhood in which ethnic and racial minorities tend to live.

\footnotetext{
${ }^{10}$ Anthropologists have also observed that social groups seek to preserve their identity, an activity that accelerates when threats to internal cohesion intensify. For an early analysis of this issue, see Whyte (1943).

${ }^{11}$ See Gallis (2005) for a survey of the actual policies regarding Muslim integration in Europe.
} 


\section{References}

[1] Bisin, A., Topa, G. and T. Verdier (2004), "Religious intermarriage and socialization in the United States," Journal of Political Economy $112,615-664$.

[2] Fryer, R.G. Jr. and P. Torelli (2005), "An Empirical Analysis of 'Acting White'," NBER Working Paper No. 11334.

[3] Constant, A., L. Gataullina, K.F. Zimmermann, and L. Zimmermann (2006), "Clash of Cultures: Muslims and Christians in the Ethnosizing Process," IZA Discussion Paper No. 2350.

[4] Gallis, P. (Coordinator) (2005): 'Muslims in Europe: Integration Policies in Selected Countries,' CRS Report for Congress, Congressional Research Service, The Library of Congress.

[5] Huntington, S.P. (1993), "The Clash of Civilizations?" Foreign Affairs $72,22-49$.

[6] Huntington, S.P. (1996), The Clash of Civilizations and the Remaking of World Order, New York: Simon \& Schuster.

[7] Manning, A. and S. Roy (2007), "Culture Clash or Culture Club? The Identity and Attitudes of Immigrants in Britain," CEP Discussion Paper No. 790, London School of Economics.

[8] Modood, T., R. Berthoud, J. Lakey, J. Nazroo, P. Smith, S. Virdee, S. Beishon (1997), Ethnic Minorities in Britain: Diversity and Disadvantage, London: Policy Studies Institute.

[9] Phillips, T. (2005), "After 7/7: Sleepwalking to Segregation," Speech delivered at the Manchester Council for Community Relations, 22 September 2005, available online at http://www.cre.gov.uk/Default.aspx.LocID-0hgnew07s.RefLocID0hg00900c002.Lang-EN.htm

[10] Putnam, R.D. (2007), "E Pluribus Unum: Diversity and Community in the Twenty-First Century," Scandinavian Political Studies 30, 13774 .

[11] Sen, A. (2006), Identity and Violence: The Illusion of Destiny, New York: Norton \& Company. 
[12] Thernstrom, S., Orlov, A. and O. Handlin (1980), Harvard Encyclopedia of of American Ethnic Groups, Cambridge, MA: Harvard University Press.

[13] Whyte, W.F. (1943), Street Corner Society, Chicago, University of Chicago Press (New Edition: 1993). 


\section{Appendix 1. Definition of variables}

Discrimination: Dummy variable taking value one if the respondent had been refused a job at least once or had been treated unfairly at work with regard to promotion or a move to a better position for has been attacked or insulted in the last year for reasons to do with race or color, or religious or cultural background.

Age at arrival: Respondent's age in years at arrival in the UK

Arranged marriage: Dummy variable taking value one if the husband/wife of the respondent has been chosen by the parents.

Children: Number of respondent's children.

Born in the UK: Dummy variable taking value one if the respondent is born in the UK

Female: Dummy variable taking value one if the respondent is female.

Years since arrival: Number of years since respondent's arrival in UK.

No parents: Dummy variable taking value one if both respondent's parents are dead or if both live away from respondent.

Parents' physical contacts: Number of times the respondent has seen the parents in the last four weeks.

Parents' telephone calls: Number of times the respondent has spoken to the parents on the telephone in the last four weeks.

Parents' letters: Number of letters received by the parents in the last four weeks.

No British education: Dummy variable taking value one if the respondent has no UK qualification

British basic education: Dummy variable taking value one if the respondent has a UK basic level of education.

British high education: Dummy variable taking value one if the respondent has a UK A-level (or equivalent) or above qualification.

Foreign education: Dummy variable taking value one if the respondent has a qualification achieved abroad.

Unemployed: Dummy variable taking value one if the respondent is unemployed.

Self-employed: Dummy variable taking value one if the respondent is self-employed .

Manager: Dummy variable taking value one if the respondent is a manager .

Employees: Dummy variable taking value one if the respondent is an (unskilled) employee 
English spoken at home (older): Dummy variable taking value one if English is the language normally spoken at home by the respondent to members of the family who are older.

English spoken at home (younger): Dummy variable taking value one if English is the language normally spoken at home by the respondent to members of the family who are younger.

English spoken at work: Dummy variable taking value one if English is the language normally spoken at work by the respondent.

English spoken with friends: Dummy variable taking value one if English is the language normally spoken with friends (outside work) by the respondent.

Discrimination of own ethnicity: Percentage of own ethnic group individuals that have experienced racial discrimination.

Ward unemployment rate: Ward unemployment rate (divided in six classes: below 2\%; 2\%-5\%, 5\%-10\%, 10\%-15\%, 15\%-20\%, $20 \%$ and above; mean value taken for each class).

Ward density of own ethnicity: Percentage of residents of the respondent's ethnic group in the ward (divided in seven classes; below $2 \%, 2 \%-5 \%$, $5 \%-10 \%, 10 \%-15 \%, 15 \%-25 \%, 25 \%-33 \%, 33 \%$ and above; mean value taken for each class)

Household income: Respondent's household total income from all sources, before tax (divided in sixteen classes, mean value taken for each class). 
Table 1: Description of data

\begin{tabular}{lcccc}
\hline \hline & \multicolumn{2}{c}{ Muslim } & \multicolumn{2}{c}{ Non-Muslim } \\
& n.obs.: 2,369 & n.obs.: 3,594 \\
\hline \multicolumn{1}{c}{ Variable } & Mean & St.dev. & Mean & St.dev. \\
\hline Importance of religion*** & 79.15 & 13.32 & 42.05 & 16.66 \\
Attitude towards inter-marriage*** & 70.10 & 10.42 & 36.91 & 12.43 \\
Importance of racial composition in & 64.65 & 21.34 & 33.45 & 15.35 \\
schools*** & & & & \\
Age at arrival* & 39.18 & 12.68 & 42.57 & 13.20 \\
Female & 0.47 & 0.50 & 0.48 & 0.50 \\
Born in the UK*** & 0.21 & 0.24 & 0.28 & 0.30 \\
Arranged Marriage*** & 0.22 & 0.16 & 0.12 & 0.11 \\
Discrimination & 0.17 & 0.22 & 0.19 & 0.27 \\
Children** & 2.17 & 1.24 & 1.68 & 0.75 \\
Years since arrival & 26.43 & 10.27 & 27.08 & 10.03 \\
No British education** & 0.81 & 0.37 & 0.52 & 0.50 \\
British basic education** & 0.06 & 0.24 & 0.13 & 0.36 \\
British high education** & 0.08 & 0.17 & 0.16 & 0.46 \\
Foreign education & 0.25 & 0.43 & 0.29 & 0.46 \\
Unemployed** & 0.19 & 0.39 & 0.08 & 0.27 \\
Self-employed** & 0.09 & 0.29 & 0.14 & 0.34 \\
Manager** & 0.02 & 0.11 & 0.04 & 0.20 \\
Employee*** & 0.38 & 0.49 & 0.59 & 0.49 \\
No parents** & 0.34 & 0.47 & 0.32 & 0.47 \\
Parents' physical contacts** & 3.05 & 7.01 & 3.87 & 7.06 \\
Parents' telephone calls*** & 3.38 & 7.05 & 4.74 & 7.48 \\
Parents' letters*** & 0.67 & 1.10 & 0.37 & 0.77 \\
English spoken at home (older)*** & 0.03 & 0.18 & 0.08 & 0.27 \\
English spoken at home (younger)** & 0.20 & 0.40 & 0.25 & 0.43 \\
English spoken with friends** & 0.22 & 0.42 & 0.27 & 0.44 \\
English spoken at work*** & 0.19 & 0.40 & 0.27 & 0.44 \\
Household income*** & 200.74 & 135.31 & 330.26 & 207.72 \\
Discrimination of own ethnicity* & 21.16 & 17.09 & 18.08 & 16.90 \\
Ward density of own ethnicity** & 15.20 & 11.20 & 11.63 & 9.96 \\
Ward unemployment rate** & 16.67 & 4.46 & 12.60 & 5.07 \\
& & & & \\
\hline
\end{tabular}

Notes:

- T-tests for differences in means across groups are performed. Variables marked with * $\left(^{* *}\right)$ [***] denote differences in mean values that are significant at the 10 (5) [1] percent level 
Table 2: The development of an identity

(1) Dependent variable: importance of religion

(2) Dependent variable: attitude towards inter-marriage

(3) Dependent variable: importance of racial composition in schools

\begin{tabular}{|c|c|c|c|c|c|c|}
\hline & \multicolumn{2}{|c|}{ (1) } & \multicolumn{2}{|c|}{ (2) } & \multicolumn{2}{|c|}{ (3) } \\
\hline & Muslim & $\begin{array}{c}\text { Non- } \\
\text { Muslim }\end{array}$ & Muslim & $\begin{array}{c}\text { Non- } \\
\text { Muslim }\end{array}$ & Muslim & $\begin{array}{c}\text { Non- } \\
\text { Muslim }\end{array}$ \\
\hline Variable & $\begin{array}{c}\text { Marginal } \\
\text { effect } \\
\text { (p-value) }\end{array}$ & $\begin{array}{c}\text { Marginal } \\
\text { effect } \\
\text { (p-value) }\end{array}$ & $\begin{array}{c}\text { Marginal } \\
\text { effect } \\
\text { ( } p \text {-value) }\end{array}$ & $\begin{array}{c}\text { Marginal } \\
\text { effect } \\
\text { ( } p \text {-value) }\end{array}$ & $\begin{array}{c}\text { Marginal } \\
\text { effect } \\
\text { (p-value) }\end{array}$ & $\begin{array}{l}\text { Marginal } \\
\text { effect } \\
\text { (p-value) }\end{array}$ \\
\hline Age at arrival & $\begin{array}{l}-0.0069 \\
(0.1754)\end{array}$ & $\begin{array}{l}0.0081 \\
(0.3302)\end{array}$ & $\begin{array}{l}-0.0046 \\
(0.2317)\end{array}$ & $\begin{array}{l}0.0058 \\
(0.3993)\end{array}$ & $\begin{array}{l}-0.0106 \\
(0.2175)\end{array}$ & $\begin{array}{l}0.0098 \\
(0.3630)\end{array}$ \\
\hline Female & $\begin{array}{l}0.0177 \\
(0.2155)\end{array}$ & $\begin{array}{l}-0.0191 \\
(0.3144)\end{array}$ & $\begin{array}{l}0.0217 \\
(0.2015)\end{array}$ & $\begin{array}{l}0.0112 \\
(0.3011)\end{array}$ & $\begin{array}{l}0.0451 \\
(0.2661)\end{array}$ & $\begin{array}{l}-0.0319 \\
(0.3331)\end{array}$ \\
\hline Born in the UK & $\begin{array}{l}-0.0089 * * \\
(0.0151)\end{array}$ & $\begin{array}{l}-0.0189 * * \\
(0.0188)\end{array}$ & $\begin{array}{l}-0.0133^{* *} \\
(0.0120)\end{array}$ & $\begin{array}{l}-0.0389 * * * \\
(0.0085)\end{array}$ & $\begin{array}{l}-0.0210^{* *} \\
(0.0251)\end{array}$ & $\begin{array}{l}-0.0418^{* *} \\
(0.0388)\end{array}$ \\
\hline Arranged marriage & $\begin{array}{l}0.0119 * * \\
(0.0153)\end{array}$ & $\begin{array}{l}0.0236 \\
(0.1221)\end{array}$ & $\begin{array}{l}0.0311^{* *} \\
(0.0103)\end{array}$ & $\begin{array}{l}0.0523 \\
(0.0666)\end{array}$ & $\begin{array}{l}0.0541 * * \\
(0.0111)\end{array}$ & $\begin{array}{l}0.1023 \\
(0.1002)\end{array}$ \\
\hline Discrimination & $\begin{array}{l}0.0672 * * \\
(0.0450)\end{array}$ & $\begin{array}{l}0.0405^{* *} \\
(0.0379)\end{array}$ & $\begin{array}{l}0.0650 * * \\
(0.0451)\end{array}$ & $\begin{array}{l}0.0398 * * \\
(0.0307)\end{array}$ & $\begin{array}{l}0.0965 * * * \\
(0.0074)\end{array}$ & $\begin{array}{l}0.0554 * * * \\
(0.0037)\end{array}$ \\
\hline Children & $\begin{array}{l}0.0759 * * \\
(0.0120)\end{array}$ & $\begin{array}{l}0.0605^{* *} \\
(0.0295)\end{array}$ & $\begin{array}{l}0.0799 * * \\
(0.0115)\end{array}$ & $\begin{array}{l}0.0669 * * \\
(0.0209)\end{array}$ & $\begin{array}{l}0.1575^{* *} \\
(0.0120)\end{array}$ & $\begin{array}{l}0.1306 * * \\
(0.0129)\end{array}$ \\
\hline Years since arrival & $\begin{array}{l}-0.0070^{*} \\
(0.0722)\end{array}$ & $\begin{array}{l}-0.0212^{* *} \\
(0.0190)\end{array}$ & $\begin{array}{l}-0.0079 \\
(0.1022)\end{array}$ & $\begin{array}{l}-0.0259 * * \\
(0.0112)\end{array}$ & $\begin{array}{l}-0.0107 \\
(0.1001)\end{array}$ & $\begin{array}{l}-0.0475^{* *} \\
(0.0201)\end{array}$ \\
\hline No British education & $\begin{array}{l}0.0210 \\
(0.4039)\end{array}$ & $\begin{array}{l}0.0599 \\
(0.2997)\end{array}$ & $\begin{array}{l}0.0249 \\
(0.4153)\end{array}$ & $\begin{array}{l}0.0665 \\
(0.2655)\end{array}$ & $\begin{array}{l}0.1024 \\
(0.3970)\end{array}$ & $\begin{array}{l}0.1575 \\
(0.2876)\end{array}$ \\
\hline British basic education & $\begin{array}{l}0.0002 \\
(0.3645)\end{array}$ & $\begin{array}{l}0.0015 \\
(0.2370)\end{array}$ & $\begin{array}{l}0.0001 \\
(0.3224)\end{array}$ & $\begin{array}{l}0.0010 \\
(0.2095)\end{array}$ & $\begin{array}{l}0.0100 \\
(0.2465)\end{array}$ & $\begin{array}{l}0.0201 \\
(0.1720)\end{array}$ \\
\hline British high education & $\begin{array}{l}-0.0513 \\
(0.3457)\end{array}$ & $\begin{array}{l}-0.0807 * * * \\
(0.0010)\end{array}$ & $\begin{array}{l}-0.0533 \\
(0.3045)\end{array}$ & $\begin{array}{l}-0.0888 * * * \\
(0.0007)\end{array}$ & $\begin{array}{l}-0.0633 \\
(0.4335)\end{array}$ & $\begin{array}{l}-0.1070 * * * \\
(0.0026)\end{array}$ \\
\hline Foreign education & $\begin{array}{l}0.0346 \\
(0.2425)\end{array}$ & $\begin{array}{l}0.0501 * * * \\
(0.0032)\end{array}$ & $\begin{array}{l}0.0366 \\
(0.2624)\end{array}$ & $\begin{array}{l}0.0601^{* *} \\
(0.0123)\end{array}$ & $\begin{array}{l}0.0469 \\
(0.2825)\end{array}$ & $\begin{array}{l}0.0580 * * \\
(0.0223)\end{array}$ \\
\hline Unemployed & $\begin{array}{l}-0.0542 \\
(0.2190)\end{array}$ & $\begin{array}{l}0.1003 \\
(0.3971)\end{array}$ & $\begin{array}{l}-0.0492 \\
(0.1990)\end{array}$ & $\begin{array}{l}0.0985 \\
(0.3884)\end{array}$ & $\begin{array}{l}-0.0742 \\
(0.2905)\end{array}$ & $\begin{array}{l}0.1440 \\
(0.4559)\end{array}$ \\
\hline Self-employed & $\begin{array}{l}0.0105 \\
(0.2219)\end{array}$ & $\begin{array}{l}0.0048 \\
(0.2950)\end{array}$ & $\begin{array}{l}0.0118 \\
(0.3192)\end{array}$ & $\begin{array}{l}-0.0085 \\
(0.3504)\end{array}$ & $\begin{array}{l}0.0105 \\
(0.1870)\end{array}$ & $\begin{array}{l}-0.0034 \\
(0.2512)\end{array}$ \\
\hline Manager & $\begin{array}{l}0.0651^{* *} \\
(0.0235)\end{array}$ & $\begin{array}{l}-0.0499 * \\
(0.0813)\end{array}$ & $\begin{array}{l}0.0617 * * \\
(0.0204)\end{array}$ & $\begin{array}{l}-0.0485 * * \\
(0.0487)\end{array}$ & $\begin{array}{l}0.0717^{* *} \\
(0.0211)\end{array}$ & $\begin{array}{l}-0.0928^{* * *} \\
(0.0078)\end{array}$ \\
\hline Employee & $\begin{array}{l}0.0672 \\
(0.5020)\end{array}$ & $\begin{array}{l}0.0605 \\
(0.6042)\end{array}$ & $\begin{array}{l}0.0702 \\
(0.5332)\end{array}$ & $\begin{array}{l}0.0635 \\
(0.6217)\end{array}$ & $\begin{array}{l}0.1720 \\
(0.5920)\end{array}$ & $\begin{array}{l}0.1663 \\
(0.6817)\end{array}$ \\
\hline No parents & $\begin{array}{l}0.0508 * * \\
(0.0144)\end{array}$ & $\begin{array}{l}0.0122 \\
(0.1121)\end{array}$ & $\begin{array}{l}0.0598 * * \\
(0.0164)\end{array}$ & $\begin{array}{l}0.0169 \\
(0.1320)\end{array}$ & $\begin{array}{l}0.0435 * * \\
(0.0105)\end{array}$ & $\begin{array}{l}0.0115 \\
(0.1066)\end{array}$ \\
\hline Parents' physical contacts & $\begin{array}{l}0.0464 * * \\
(0.0130)\end{array}$ & $\begin{array}{l}0.0158 \\
(0.1765)\end{array}$ & $\begin{array}{l}0.0699 * * * \\
(0.0099)\end{array}$ & $\begin{array}{l}0.0300 \\
(0.1585)\end{array}$ & $\begin{array}{l}0.0434 * * \\
(0.0333)\end{array}$ & $\begin{array}{l}0.0113 * \\
(0.0918)\end{array}$ \\
\hline Parents' telephone calls & $\begin{array}{l}0.0349 * * \\
(0.0405)\end{array}$ & $\begin{array}{l}0.0070 \\
(0.3345)\end{array}$ & $\begin{array}{l}0.0432 * * \\
(0.0345)\end{array}$ & $\begin{array}{l}0.0175 \\
(0.4053)\end{array}$ & $\begin{array}{l}0.0243^{* *} \\
(0.0459)\end{array}$ & $\begin{array}{l}0.0037 \\
(0.3445)\end{array}$ \\
\hline Parents' letters & $\begin{array}{l}0.0708 * * * \\
(0.0076)\end{array}$ & $\begin{array}{l}0.0205^{* *} \\
(0.0302)\end{array}$ & $\begin{array}{l}0.0678 * * \\
(0.0162)\end{array}$ & $\begin{array}{l}0.0211^{* *} \\
(0.0212)\end{array}$ & $\begin{array}{l}0.0978 * * * \\
(0.0062)\end{array}$ & $\begin{array}{l}0.0520 * * * \\
(0.0012)\end{array}$ \\
\hline English spoken at home (older) & $\begin{array}{l}-0.0999 * * \\
(0.0177)\end{array}$ & $\begin{array}{l}-0.0755^{* *} \\
(0.0209)\end{array}$ & $\begin{array}{l}-0.1091^{* *} \\
(0.0195)\end{array}$ & $\begin{array}{l}-0.0555^{* *} \\
(0.0225)\end{array}$ & $\begin{array}{l}-0.1901^{* * * *} \\
(0.0003)\end{array}$ & $\begin{array}{l}-0.1555^{* *} \\
(0.0129)\end{array}$ \\
\hline English spoken at home (younger) & $\begin{array}{l}-0.0458 * * \\
(0.0117)\end{array}$ & $\begin{array}{l}-0.0321 \\
(0.1436)\end{array}$ & $\begin{array}{l}-0.0576 * * \\
(0.0312)\end{array}$ & $\begin{array}{l}-0.0389 \\
(0.1036)\end{array}$ & $\begin{array}{l}-0.0596 * * \\
(0.0412)\end{array}$ & $\begin{array}{l}-0.0369 \\
(0.1553)\end{array}$ \\
\hline English spoken at work & $\begin{array}{l}0.0707 * \\
(0.0762)\end{array}$ & $\begin{array}{l}0.0198 * \\
(0.0798)\end{array}$ & $\begin{array}{l}0.0697 * \\
(0.0902)\end{array}$ & $\begin{array}{l}0.0210^{*} \\
(0.0989)\end{array}$ & $\begin{array}{l}0.0509 * \\
(0.0602)\end{array}$ & $\begin{array}{l}0.0102 * \\
(0.0799)\end{array}$ \\
\hline English spoken with friends & $\begin{array}{l}-0.0672 * * \\
(0.0306)\end{array}$ & $\begin{array}{l}-0.0340 * * \\
(0.0478)\end{array}$ & $\begin{array}{l}-0.0671^{* * * *} \\
(0.0077)\end{array}$ & $\begin{array}{l}-0.0414 * * \\
(0.0500)\end{array}$ & $\begin{array}{l}-0.0772 * * * \\
(0.0076)\end{array}$ & $\begin{array}{l}-0.0540 * * \\
(0.0482)\end{array}$ \\
\hline Household income & $\begin{array}{l}0.0009 * * \\
(0.0201)\end{array}$ & $\begin{array}{l}-0.0005 \\
(0.4557)\end{array}$ & $\begin{array}{l}0.0017^{* *} \\
(0.0253)\end{array}$ & $\begin{array}{l}-0.0010 \\
(0.4253)\end{array}$ & $\begin{array}{l}0.0019 * * \\
(0.0121)\end{array}$ & $\begin{array}{l}-0.0015 \\
(0.4075)\end{array}$ \\
\hline Discrimination of own ethnicity & $0.0801^{* * *}$ & $0.0500 * *$ & $0.0880 * * *$ & $0.0560 * * *$ & $0.1400 * * *$ & $0.1131^{* * *}$ \\
\hline
\end{tabular}




$\begin{array}{lllllll} & (0.0066) & (0.0135) & (0.0026) & (0.0093) & (0.0026) & (0.0035) \\ \text { Ward density of own ethnic group } & -0.0193^{* *} & -0.0098^{* *} & -0.0173^{* *} & -0.0086^{* *} & -0.0201^{* *} & -0.0058^{* *} \\ & (0.0128) & (0.0345) & (0.0180) & (0.0359) & (0.0185) & (0.0450) \\ \text { Ward unemployment rate } & -0.0280^{* *} & 0.0199 & -0.0289 * * & 0.0189 & -0.0442^{* *} & 0.0192 \\ & (0.0413) & (0.3269) & (0.0430) & (0.3355) & (0.0370) & (0.3009)\end{array}$

Notes:

- $\quad$ marginal effects at the sample means

- $\quad$ * significant at $10 \%$; ** significant at $5 \%$; *** significant at $1 \%$

- a constant and regional dummies are included

- $\quad$ results weighted for population proportions 
Table 3: Ethnic identity in different sub-samples

Sub-sample (1): individuals declaring that their residential area is poor for being with other people of their own ethnic group but prefer to stay

Sub-sample (2): individuals declaring that their residential area is good for being with other people of their own ethnic group and are willing to move out from the area

\begin{tabular}{|c|c|c|c|c|c|c|}
\hline Variable & $\begin{array}{c}\text { Entire } \\
\text { sample }\end{array}$ & & $\begin{array}{c}\text { Sub- } \\
\text { sample (1) } \\
\end{array}$ & & & $\begin{array}{c}\text { Sub- } \\
\text { sample (2) }\end{array}$ \\
\hline & Muslims & $\begin{array}{c}\text { Non } \\
\text { Muslims }\end{array}$ & Muslims & $\begin{array}{c}\text { Non } \\
\text { Muslims }\end{array}$ & Muslims & $\begin{array}{c}\text { Non } \\
\text { Muslims }\end{array}$ \\
\hline importance of religion & $\begin{array}{c}79.15 \\
(13.32)\end{array}$ & $\begin{array}{c}42.05 \\
(16.66)\end{array}$ & $\begin{array}{c}78.65 \\
(19.94)\end{array}$ & $\begin{array}{c}41.90 \\
(17.40)\end{array}$ & $\begin{array}{c}79.77 \\
(15.26)\end{array}$ & $\begin{array}{c}42.39 \\
(15.54)\end{array}$ \\
\hline attitude towards inter-marriage & $\begin{array}{c}70.10 \\
(10.42)\end{array}$ & $\begin{array}{c}36.91 \\
(12.43)\end{array}$ & $\begin{array}{c}72.07 \\
(13.66)\end{array}$ & $\begin{array}{c}35.69 \\
(11.24)\end{array}$ & $\begin{array}{l}71.36 \\
(12.49)\end{array}$ & $\begin{array}{c}37.06 \\
(14.05)\end{array}$ \\
\hline $\begin{array}{l}\text { importance of racial composition in } \\
\text { schools }\end{array}$ & $\begin{array}{c}64.65 \\
(21.34)\end{array}$ & $\begin{array}{c}33.45 \\
(15.35)\end{array}$ & $\begin{array}{c}63.55 \\
(20.40)\end{array}$ & $\begin{array}{c}33.91 \\
(16.24)\end{array}$ & $\begin{array}{c}64.95 \\
(22.12)\end{array}$ & $\begin{array}{c}32.80 \\
(17.03)\end{array}$ \\
\hline
\end{tabular}

Notes:

- $\quad$ Means and standard deviations (in parentheses) are reported

- T-tests for differences in means for all pairs of groups are performed. None of them is found to be statistical significant at any conventional level of probability. 


\section{Table 4: The development of an identity}

Robustness check

Sub-sample (a): individuals declaring that their residential area is poor for being with other people of their own ethnic group but prefer to stay

Sub-sample (b): individuals declaring that their residential area is good for being with other people of their own ethnic group and are willing to move out from the area

Dependent variable: importance of religion

\begin{tabular}{|c|c|c|c|c|}
\hline & \multicolumn{2}{|c|}{ Muslim } & \multicolumn{2}{|c|}{ Non-Muslim } \\
\hline & (a) & (b) & (a) & (b) \\
\hline Variable & $\begin{array}{c}\text { Marginal } \\
\text { effect } \\
(p \text {-value) }\end{array}$ & $\begin{array}{c}\text { Marginal } \\
\text { effect } \\
\text { (p-value) }\end{array}$ & $\begin{array}{c}\text { Marginal } \\
\text { effect } \\
(p \text {-value) }\end{array}$ & $\begin{array}{c}\text { Marginal } \\
\text { effect } \\
\text { (p-value) }\end{array}$ \\
\hline Age at arrival & $\begin{array}{l}-0.0016 \\
(0.1859)\end{array}$ & $\begin{array}{l}0.0089 \\
(0.3530)\end{array}$ & $\begin{array}{l}-0.0006 \\
(0.2875)\end{array}$ & $\begin{array}{l}0.0018 \\
(0.3930)\end{array}$ \\
\hline Female & $\begin{array}{l}0.0265 \\
(0.2644)\end{array}$ & $\begin{array}{l}-0.0199 \\
(0.3445)\end{array}$ & $\begin{array}{l}0.0499 \\
(0.2699)\end{array}$ & $\begin{array}{l}-0.0355 \\
(0.3433)\end{array}$ \\
\hline Born in the UK & $\begin{array}{l}-0.0109 * * \\
(0.0215)\end{array}$ & $\begin{array}{l}-0.0185 * * \\
(0.0218)\end{array}$ & $\begin{array}{l}-0.0255^{* *} \\
(0.0332)\end{array}$ & $\begin{array}{l}-0.0421 * * \\
(0.0403)\end{array}$ \\
\hline Arranged marriage & $\begin{array}{l}0.0105^{* *} \\
(0.0165)\end{array}$ & $\begin{array}{l}0.0213^{*} \\
(0.0462)\end{array}$ & $\begin{array}{l}0.0505^{* *} \\
(0.0222)\end{array}$ & $\begin{array}{l}0.0782 \\
(0.1011)\end{array}$ \\
\hline Discrimination & $\begin{array}{l}0.0882^{* *} \\
(0.0345)\end{array}$ & $\begin{array}{l}0.0664 * * \\
(0.0387)\end{array}$ & $\begin{array}{l}0.0779 * * \\
(0.0179)\end{array}$ & $\begin{array}{l}0.0455^{* * *} \\
(0.0203)\end{array}$ \\
\hline Children & $\begin{array}{l}0.0799 * * \\
(0.0132)\end{array}$ & $\begin{array}{l}0.0805^{* *} \\
(0.0299)\end{array}$ & $\begin{array}{l}0.1590 * * \\
(0.0220)\end{array}$ & $\begin{array}{l}0.1430 * * \\
(0.0341)\end{array}$ \\
\hline Years since arrival & $\begin{array}{l}-0.0087 \\
(0.1072)\end{array}$ & $\begin{array}{l}-0.0210^{* *} \\
(0.0218)\end{array}$ & $\begin{array}{l}-0.0110 \\
(0.1199)\end{array}$ & $\begin{array}{l}-0.0405^{* *} \\
(0.0321)\end{array}$ \\
\hline No British education & $\begin{array}{l}0.0288 \\
(0.5050)\end{array}$ & $\begin{array}{l}0.0759 \\
(0.3529)\end{array}$ & $\begin{array}{l}0.1202 \\
(0.4947)\end{array}$ & $\begin{array}{l}0.1457 \\
(0.3857)\end{array}$ \\
\hline British basic education & $\begin{array}{l}0.0006 \\
(0.3664)\end{array}$ & $\begin{array}{l}0.0019 \\
(0.2537)\end{array}$ & $\begin{array}{l}0.0111 \\
(0.2669)\end{array}$ & $\begin{array}{l}0.0255 \\
(0.1972)\end{array}$ \\
\hline British high education & $\begin{array}{l}-0.0544 \\
(0.3845)\end{array}$ & $\begin{array}{l}-0.0980 * * * \\
(0.0100)\end{array}$ & $\begin{array}{l}-0.0763 \\
(0.4533)\end{array}$ & $\begin{array}{l}-0.1115^{* * *} \\
(0.0079)\end{array}$ \\
\hline Foreign education & $\begin{array}{l}0.0304 \\
(0.3472)\end{array}$ & $\begin{array}{l}0.0515^{* *} \\
(0.0203)\end{array}$ & $\begin{array}{l}0.0408 \\
(0.3282)\end{array}$ & $\begin{array}{l}0.0445^{* *} \\
(0.0278)\end{array}$ \\
\hline Unemployed & $\begin{array}{l}-0.0454 \\
(0.4210)\end{array}$ & $\begin{array}{l}0.1100 \\
(0.5359)\end{array}$ & $\begin{array}{l}-0.0702 \\
(0.3829)\end{array}$ & $\begin{array}{l}0.1344 \\
(0.4995)\end{array}$ \\
\hline Self-employed & $\begin{array}{l}0.0120 \\
(0.3322)\end{array}$ & $\begin{array}{l}0.0004 \\
(0.3995)\end{array}$ & $\begin{array}{l}0.0099 \\
(0.2887)\end{array}$ & $\begin{array}{l}-0.0013 \\
(0.3925)\end{array}$ \\
\hline Manager & $\begin{array}{l}0.0765^{* *} \\
(0.0323)\end{array}$ & $\begin{array}{l}-0.0564 * \\
(0.0801)\end{array}$ & $\begin{array}{l}0.0799 * * \\
(0.0299)\end{array}$ & $\begin{array}{l}-0.0892 * * \\
(0.0207)\end{array}$ \\
\hline Employee & $\begin{array}{l}0.0607 \\
(0.5402)\end{array}$ & $\begin{array}{l}0.0609 \\
(0.6099)\end{array}$ & $\begin{array}{l}0.1507 \\
(0.5992)\end{array}$ & $\begin{array}{l}0.1466 \\
(0.6681)\end{array}$ \\
\hline No parents & $\begin{array}{l}0.0450 * \\
(0.0514)\end{array}$ & $\begin{array}{l}0.0102 \\
(0.1441)\end{array}$ & $\begin{array}{l}0.0224 * * \\
(0.0166)\end{array}$ & $\begin{array}{l}0.0091 \\
(0.1106)\end{array}$ \\
\hline Parents' physical contacts & $\begin{array}{l}0.0488^{* *} \\
(0.0210)\end{array}$ & $\begin{array}{l}0.0145 \\
(0.1876)\end{array}$ & $\begin{array}{l}0.0543^{* *} \\
(0.0493)\end{array}$ & $\begin{array}{l}0.0188 \\
(0.1309)\end{array}$ \\
\hline Parents' telephone calls & $\begin{array}{l}0.0300^{*} \\
(0.0514)\end{array}$ & $\begin{array}{l}0.0067 \\
(0.3450)\end{array}$ & $\begin{array}{l}0.0240 * * \\
(0.0499)\end{array}$ & $\begin{array}{l}0.0075 \\
(0.3564)\end{array}$ \\
\hline Parents' letters & $\begin{array}{l}0.0728 * * * \\
(0.0087)\end{array}$ & $\begin{array}{l}0.0229 * * \\
(0.0390)\end{array}$ & $\begin{array}{l}0.0917 * * \\
(0.0106)\end{array}$ & $\begin{array}{l}0.0542 * * * \\
(0.0081)\end{array}$ \\
\hline English spoken at home (older) & $\begin{array}{l}-0.0918 * * \\
(0.0215)\end{array}$ & $\begin{array}{l}-0.0798 * * \\
(0.0277)\end{array}$ & $\begin{array}{l}-0.1855^{* * *} \\
(0.0023)\end{array}$ & $\begin{array}{l}-0.1501^{* *} \\
(0.0219)\end{array}$ \\
\hline English spoken at home (younger) & $\begin{array}{l}-0.0401 * * \\
(0.03311)\end{array}$ & $\begin{array}{l}-0.0298 \\
(0.1743)\end{array}$ & $\begin{array}{l}-0.0598^{*} \\
(0.0515)\end{array}$ & $\begin{array}{l}-0.0386 \\
(0.1885)\end{array}$ \\
\hline English spoken at work & $\begin{array}{l}0.0790 * \\
(0.0876)\end{array}$ & $\begin{array}{l}0.0219 * \\
(0.0979)\end{array}$ & $\begin{array}{l}0.0560 * \\
(0.0760)\end{array}$ & $\begin{array}{l}0.0120 * \\
(0.0870)\end{array}$ \\
\hline English spoken with friends & $\begin{array}{l}-0.0697 * * \\
(0.0399)\end{array}$ & $\begin{array}{l}-0.0310^{*} \\
(0.0549)\end{array}$ & $\begin{array}{l}-0.0977 * * \\
(0.0120)\end{array}$ & $\begin{array}{l}-0.0584 * * \\
(0.0500)\end{array}$ \\
\hline Household income & $0.0018 * *$ & -0.0002 & $0.0025 * *$ & -0.0011 \\
\hline
\end{tabular}




$\begin{array}{lllll} & (0.0320) & (0.4995) & (0.0412) & (0.4755) \\ \text { Discrimination of own ethnicity } & 0.0822^{* *} & 0.0510^{* *} & 0.1440^{* *} & 0.1199^{* *} \\ & (0.0165) & (0.0251) & (0.0102) & (0.0150) \\ \text { Ward density of own ethnic group } & -0.0219^{* *} & -0.0089^{* *} & -0.0250^{* *} & -0.0065^{*} \\ & (0.0251) & (0.0453) & (0.0185) & (0.0501) \\ \text { Ward unemployment rate } & -0.0268^{* *} & 0.0201 & -0.0404^{* *} & 0.0190 \\ & (0.0451) & (0.3526) & (0.0498) & (0.3955)\end{array}$

Notes:

- $\quad$ marginal effects at the sample means

- $\quad$ * significant at 10\%; ** significant at 5\%; *** significant at $1 \%$

- a constant and regional dummies are included

- $\quad$ results weighted for population proportions 
Figure 1 : Integration patterns over time

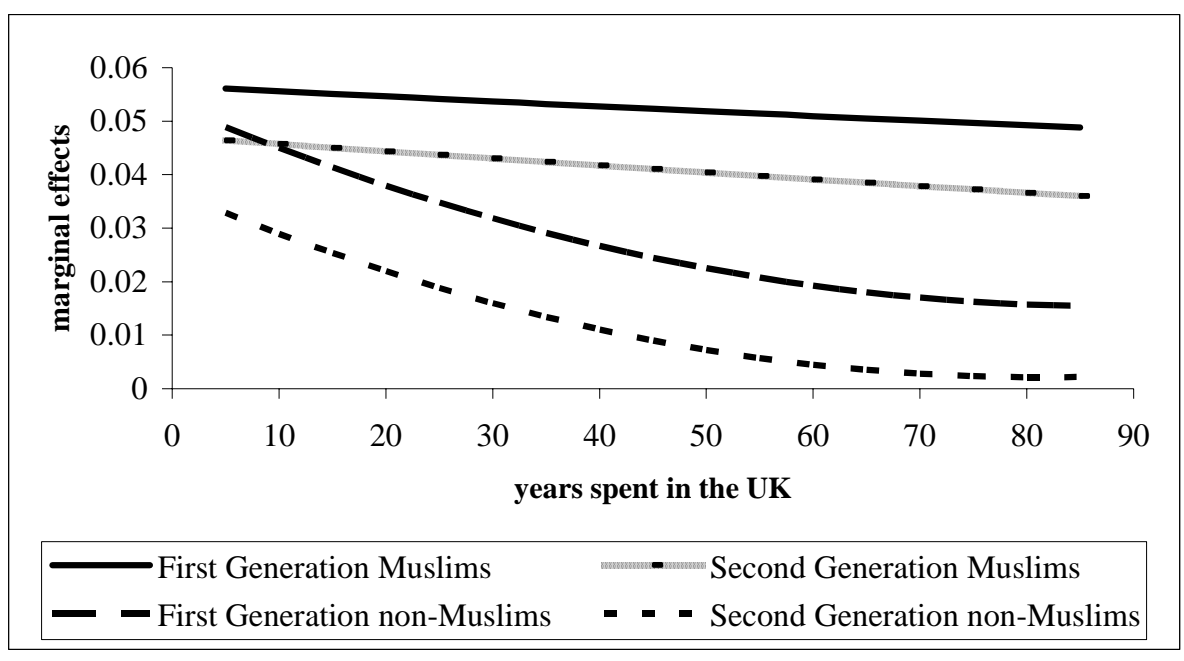

Notes:

- The marginal effects show the increase/decrease in the average probability of having a strong religious identity following a one-year increase in the time spent in the UK. The average probability, i.e. calculated at the sample means of all variables, is equal to 5.7\% and 5.3\% for Muslims and nonMuslims respectively. 